\title{
FABRIC FILTERS FOR WASTE WATER TREATMENT IN RURAL COMMUNITIES IN EGYPT
}

\author{
Bayoumi, Gihan, B. ${ }^{(1)}$; Sabry, T. I. ${ }^{(2)}$; El Gendy, A. S. ${ }^{(1)}$; \\ Saad, M. M. A. ${ }^{(3)}$ and Yehia, M. M. ${ }^{(4)}$ \\ 1) Institute of Environmental Studies \& Research, Ain Shams \\ University 2) Faculty of Engineering, Ain Shams University \\ 3) National Research Center 4) National Water Research Center
}

\begin{abstract}
Fabric filtration is a new trend in waste water reuse applications. In an attempt to improve the waste water quality resulting from a compact unit composed of an up-flow anaerobic reactor to obtain waste water effluent quality which is complying with the law 48/1982 for discharge in agricultural drains, and which can be used safely for unrestricted irrigation, this research study aims at testing the performance of four different fabric materials at the bench scale level at different operating conditions in order to identify the optimum operating conditions for the selected material. In this research, nonwoven fabrics and woven fabrics were tested as separation media. The effect of different water heads (pressure) and flux rates were tested to evaluate the fabric material removal performance. Two parameters were used to evaluate the removal of suspended solids and organic material namely; TSS and COD. Based on the results of this research study, nonwoven fabrics were found to be promising as separation media for the waste water and more effective than woven fabrics. Low flux rates and low water heads showed better results compared to high flux rates and pressure. The selected fabric material will be tested at the full scale real wastewater resulting from a village existing in a rural area in Egypt.
\end{abstract}

Key words: Fabric filtration, Wastewater treatment, Decentralized on site treatment. 
J. Environ. Sci.

Institute of Environmental Studies and Research - Ain Shams University

\section{INTRODUCTION}

In the past decade, substantial efforts and resources have been directed by the Government of Egypt to improving access, reliability and quality of water services both in urban and rural areas. The degradation of the quality of raw water at the source which is caused by the increased load of organic and chemical pollution of the country's water bodies is a real problem. Continued direct discharge into waterways of untreated sewage and industrial wastes contributes to increasing the problem, in addition to pollution from excessive use of chemical fertilizers and pesticides.

Programs for improved rural sanitation facilities rely more on decentralized on-site solutions and safe disposal of sewage and wastewater rather than on centralized large-scale public networks and treatment plants. Focusing on unbundling of sanitation projects into smaller scale projects can bring benefits at an affordable cost to those communities in rural areas in greatest need.

The development and improvement of decentralized onsite sanitation treatment solutions can help eliminate environmental problems and prevent the health risks and diseases caused by the harmful effect of untreated waste water. Onsite sanitation treatment can also help in water reuse or the recycling of reclaimed waste water for planned beneficial uses, which is emerging as an established water management practice in water stressed countries. Therefore, new 
configurations employing the best practices of sanitation technology for rural areas are needed.

This research focuses on the development and improvement of decentralized onsite sanitation treatment solutions aiming at contributing to the continuous efforts targeting an effective design and operation of a waste water treatment system serving small villages. The system is used to treat their waste water and safely dispose it into water drains or use it in unrestricted irrigation of lands.

In an attempt to tackle the sanitation problems in Egypt's rural areas, many researches took place to identify a low cost new technology to solve rural sanitation problems (Saber A. El-Shafai et al 2004-A; Saber A. El-Shafai et al 2004-B; Tawfik, A., et al 2003; Young J. C. et al 1969; Sabry, T. 2007-A). The result of some of these researches concluded that using two stages anaerobic treatment containing two compartments; Up-Flow Septic Tank followed by Anaerobic Baffled Reactor (USBR) was proven to produce wastewater with quality comparable to the water quality produced through conventional wastewater treatment plant and at lower cost (Sabry, T. et al 2007-B; Sabry, T. 2007-C; Ghobrial, F. et al 2008; Sabry, T. 2010; Sabry, T. 2011; Sabry, T. et al 2011; El Gendy, A. et al 2012; El Gendy, A. et al 2014). This technology is easy to implement and operate; therefore it would be convenient to rural areas. The benefits of using USBR system in the wastewater treatment over that of conventional energy-intensive aerobic system can be summarized as follows: 
J. Environ. Sci.

Institute of Environmental Studies and Research - Ain Shams University

- Low construction, operation, and maintenance cost with small occupied area with comparable to aerobic treatment.

- USBR system has a capability to remove high content of the biodegradable organic matter with significantly low costs with compared to the aerobic treatment.

- It produces a good source of energy in the form of methane gas especially when treating highly concentrated wastewater. This gas can be used to produce electricity (and even gas for cooking stoves).

- Low content of excess sludge compared to aerobic sludge.

- The excess sludge is highly stable with high ability to dewatering (easy to extract water from solids).

- For the monitoring operation, anaerobic treatment doesn't need highly qualified labor.

Many on-site anaerobic systems which were used as decentralized sewage treatment were used and tested at different places (F.A. ElGohary, F.A. 2002; Tawfik, A. 2004; Elmitwalli T.A. et al 2002). However, the satisfactory performance of USBR in sewage treatment indicates that this system could be used in a small scale to serve a household or in big scale to serve small to medium communities.

In order to improve the performance of the USBR system and occupying less footprint, more research studies are needed aiming at identifying options which help in reaching the quality of water that will be used in agriculture. Fabric filtration is currently gaining popularity in wastewater reuse applications. Therefore; it is the focus of this research project proposal. 


\section{MATERIALS AND METHODS}

Experimental Setup: The experiment was designed to test the removal efficiency of four fabric filters using four reactors as shown in the following Schematic diagram.

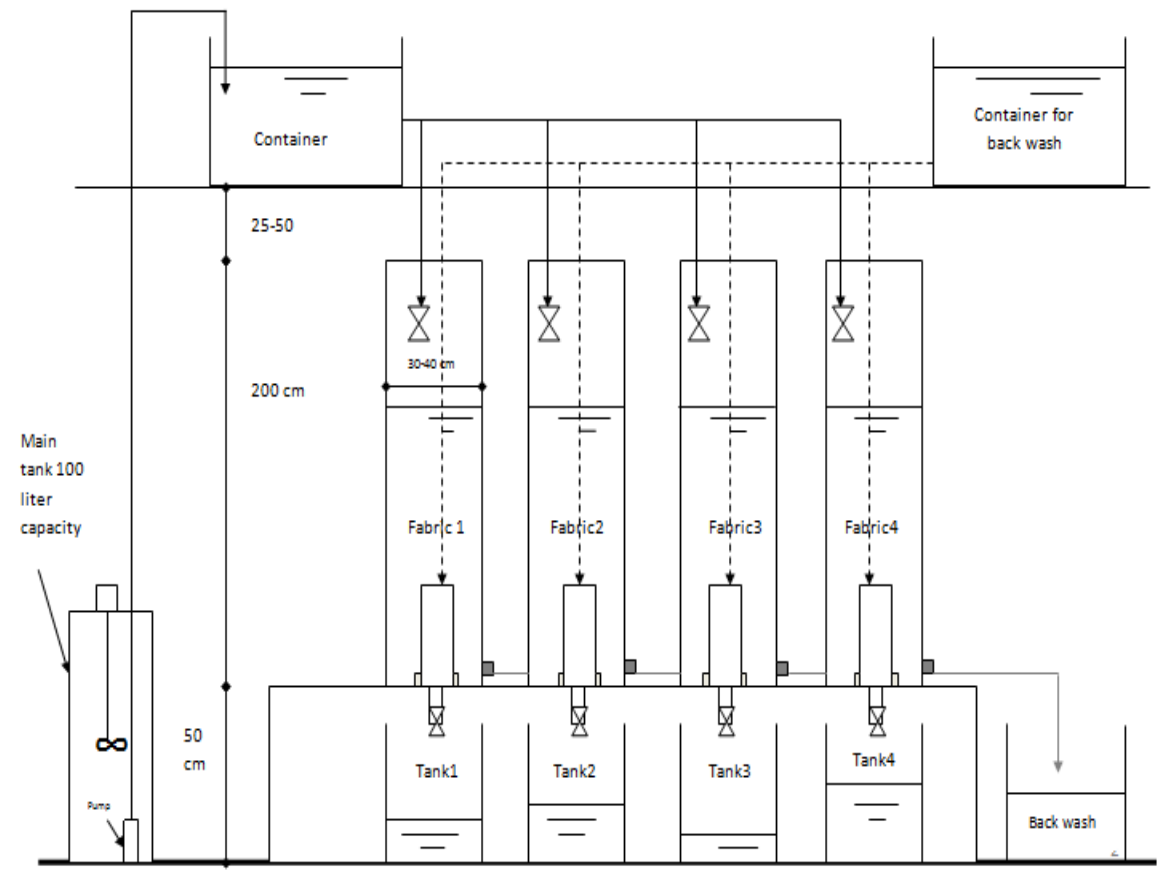

Figure (1): for the experimental setup

Four reactors were manufactured in a cylindrical shape plastic (PVC) material with diameter $40 \mathrm{~cm}$ and $200 \mathrm{~cm}$ height. The reactors were designed to accommodate the fabric filters. 


\section{Filters manufacturing:}

The fabrics are used in the research experiment to test the suitability and filtration performance of each. The fabrics used in the experiment are either non woven fabrics or woven fabrics. Non woven fabrics are known to have good filtration performance. The aim of the research was to find the most suitable filter fabric which is locally manufactured and has reasonable cost.

The filters consist of a fabric surrounding a cylindrical shape perforated metal sheet (Photo1). The height of the cylinder is $40 \mathrm{~cm}$ and its diameter is $17 \mathrm{~cm}$. The two bases of the cylindrical metal sheet are not perforated in order to prevent filtration of the waste water from the bases. Therefore, the filtration area will be through the rectangular perforated metal sheet only. The area of filtration was calculated

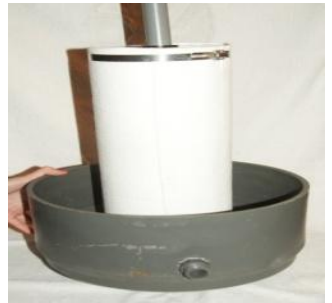

Photo 1 for each filter.

\section{Synthetic waste water preparation and composition}

A representative synthetic waste water was prepared using the following constituents namely: Peptone (Dog Food), Sucrose (Sugar), Dried Milk and Clay. Dog food and sugar are considered sources of carbohydrates and organic solids, the dried milk is considered the source of proteins and fat while the clay is considered the source of inorganic solids. The composition of these materials was chosen to 
abide by the particles composition required and to maintain the ratio of the organic constituent in the sewage; protein and fats $60 \%$, carbohydrates $40 \%$. 15 gm peptone, 15 gm sugar, 45 gm dried milk and 13.5 gm clay were mixed and added to 300 liter of fresh water resulting in synthetic waste water having the following characteristics; TSS 159 and COD 210. The waste water characteristics are similar to the waste water characteristics resulting from the USBR mentioned previously.

\section{Description of the fabric material}

Various fabrics were tested in the laboratory experiment to test the suitability of the various materials.

\section{1- Non woven fabric material:}

Non-woven fabric material is made from long fibers, bonded together by chemical, mechanical, heat or solvent treatment. Nonwoven fabrics are broadly defined as sheet or web structures bonded together by entangling fiber or filaments (and by perforating films) mechanically, thermally or chemically. They are flat, porous sheets that are made directly from separate fibers or from molten plastic or plastic film. They are not made by weaving or knitting and do not require converting the fibers to yarn. Nonwoven fabrics are engineered fabrics that may be a limited life, single-use fabric or a very durable fabric. Nonwoven fabrics provide specific functions such as absorbency, liquid repellence, resilience, stretch, softness, strength, flame retardancy, washability, cushioning, filtering, use as a bacterial barrier and sterility. 


\section{2- Woven fabric material}

Woven fabrics are made by using two or more sets of yarn interlaced at right angles to each other. Woven fabrics are generally durable. However the raw edges ravel or fray easily and need to be protected. Fabrics having more fabric count (number of wrap and weft yearns present) keep the shape well. Low count fabrics are less durable and may snag or stretch. Strength, durability, cost, and stretch make polyester material the most widely used in fabric structures. Polyesters that are laminated or coated with PVC films are usually the least expensive option for longer-term fabrications.

In this experiment, 4 fabric filters namely $\mathrm{C} 1, \mathrm{C} 2, \mathrm{C} 3$ and $\mathrm{C} 4$ were tested.

The characteristics of the fabrics are as described in Table 1.

Table (1) : Characteristics of the four fabrics

\begin{tabular}{|c|c|c|c|c|}
\hline & Type of Fabric & $\begin{array}{c}\text { Weight } \\
\text { (gm/m2) }\end{array}$ & $\begin{array}{c}\text { Water permeability at 150 } \\
\text { cm head ( L / m2 / sec) }\end{array}$ & $\begin{array}{c}\text { Thicknes } \\
\text { s (mm) }\end{array}$ \\
\hline \hline C1 & Non woven Fabric & 375 & 3.03 & 2.57 \\
\hline C2 & $\begin{array}{c}\text { Non woven fabric } \\
\text { coated with teflon } \\
\text { membrane }\end{array}$ & 542 & $*$ & 1.77 \\
\hline C3 & $\begin{array}{c}\text { Woven Twill light } \\
\text { from high density } \\
\text { fibers }\end{array}$ & 298 & 2.78 & 0.75 \\
\hline C4 & $\begin{array}{c}\text { Non woven } \\
\text { polyester low cost }\end{array}$ & 460 & 2.86 & 1.08 \\
\hline
\end{tabular}

*Initial water permeability then blocked under static pressure 
Operating Parameters: Three water heads were tested; $\mathrm{H} 1=150 \mathrm{~cm}$, $\mathrm{H} 2=175 \mathrm{~cm}$ and $\mathrm{H} 3=200 \mathrm{~cm}$. Two flux rates were tested; $\mathrm{F} 1=36$ lit $/ \mathrm{hr} \mathrm{m}^{2}$ and F2=88 lit $/ \mathrm{hr}^{2} \mathrm{~m}^{2}$

Sampling and analysis: The water samples were collected from each reactor after one hour of filtration then every two hours. The flow of water remains for 8 hours per day.

Two parameters were analyzed for all samples in the laboratory; Total Suspended Solids (TSS) and Chemical Oxygen Demand (COD).

\section{RESULTS AND DISCUSSIONS}

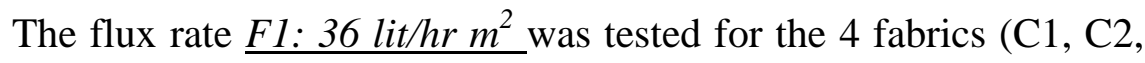
C3 and C4). When testing each fabric with the determined flux rate (F1), 3 water heads $(\mathrm{H} 1, \mathrm{H} 2$ and $\mathrm{H} 3)$ were tested each in a separate experiment, in order to assess the best water head and best fabric which gives the best removal efficiency for TSS and COD. The results are compared with the Egyptian law limits which are $50 \mathrm{mg} / \mathrm{lit}$ for TSS and $80 \mathrm{mg} / \mathrm{lit}$ for COD.

TSS removal: Fabrics C1, C2, C3 and C4 were tested for water head $(\mathrm{H} 1=150 \mathrm{~cm})$ as shown in Figure (2): TSS versus Time using F1, H1. 


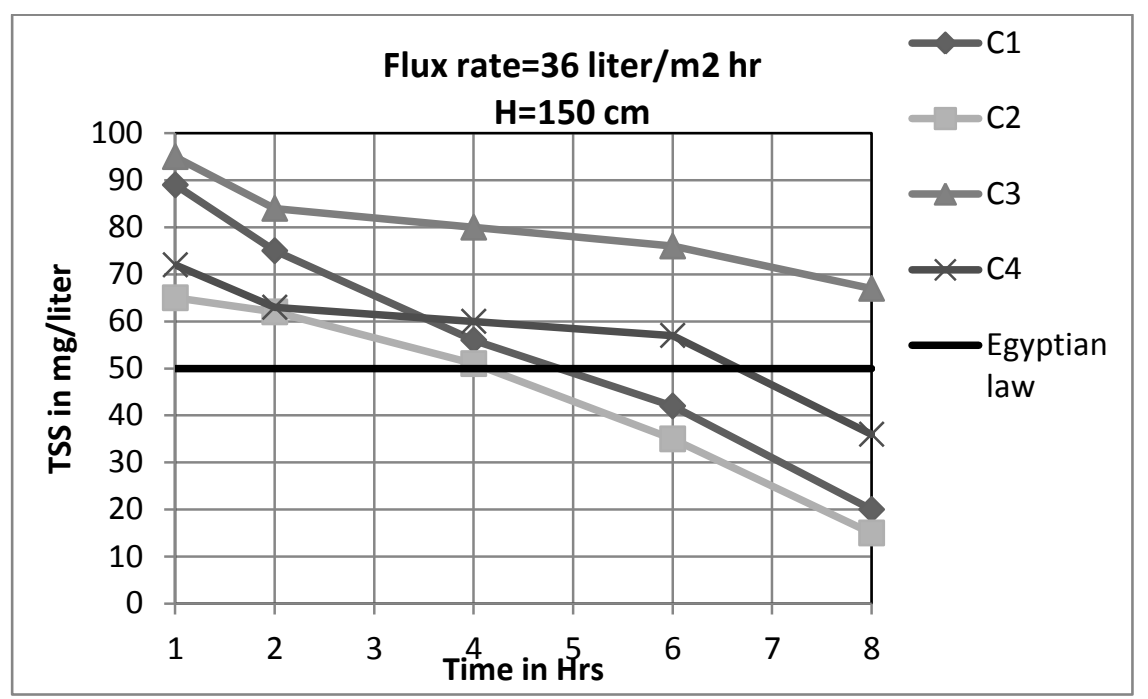

Figure (2): TSS versus Time using F1, H1

It is clear that the 3 fabrics $\mathrm{C} 1, \mathrm{C} 2$ and $\mathrm{C} 4$ succeeded to reach the Egyptian law limit after 4,5 and 6.5 hours respectively of operation under $\mathrm{F} 1$ and $\mathrm{H} 1$ conditions.

Fabrics C1, C2, C3 and C4 were tested for water head $(\mathrm{H} 2=175$ $\mathrm{cm}$ ) as shown in Figure (3): TSS versus Time using F1, H2. 


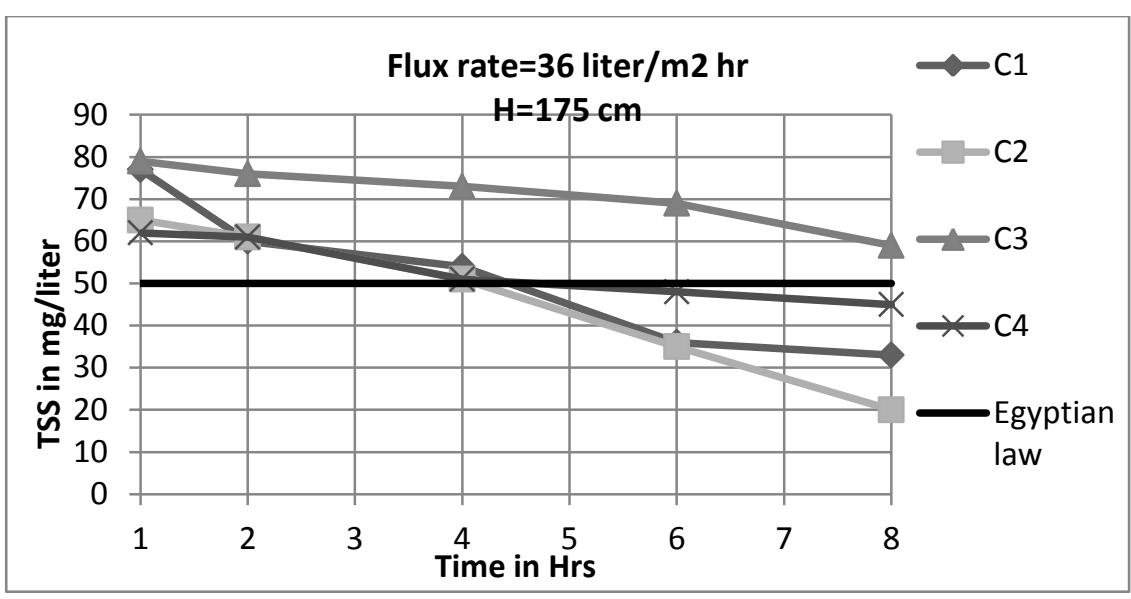

Figure (3): TSS versus Time using F1, H2

Fabrics C1, C2 and C4 succeeded to reach the Egyptian law limit after 4 hours of operation under $\mathrm{F} 1$ and $\mathrm{H} 2$ conditions.

Fabrics C1, C2, C3 and C4 were tested for water head $(\mathrm{H} 3=200$ $\mathrm{cm}$ ) as shown in Figure (4): TSS versus Time using F1, H3.

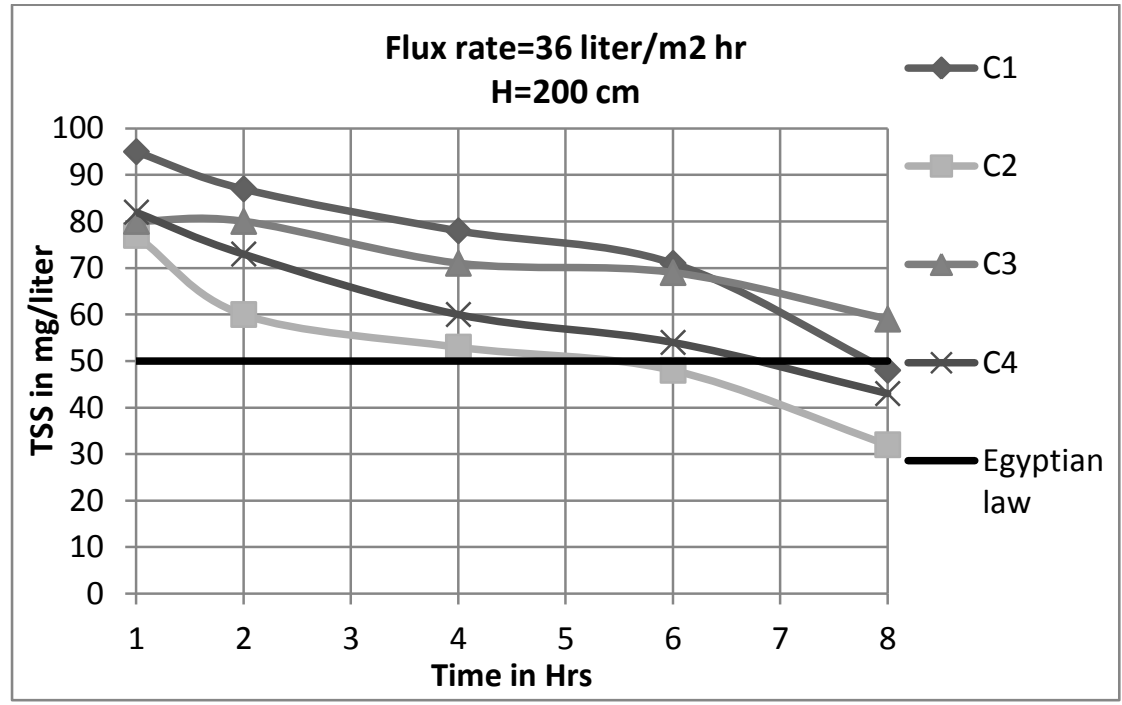

Figure (4): TSS versus Time using F1, H3 
Fabrics C2 and C4 succeeded to reach the Egyptian law limit after 6 and 7 hours of operation respectively under F1 and H3 conditions.

\section{COD removal:}

Fabrics C1, C2, C3 and C4 were tested for water head $(\mathrm{H} 1=150$ $\mathrm{cm}$ ) as shown in Figure (5) : COD versus Time using F1, H1.

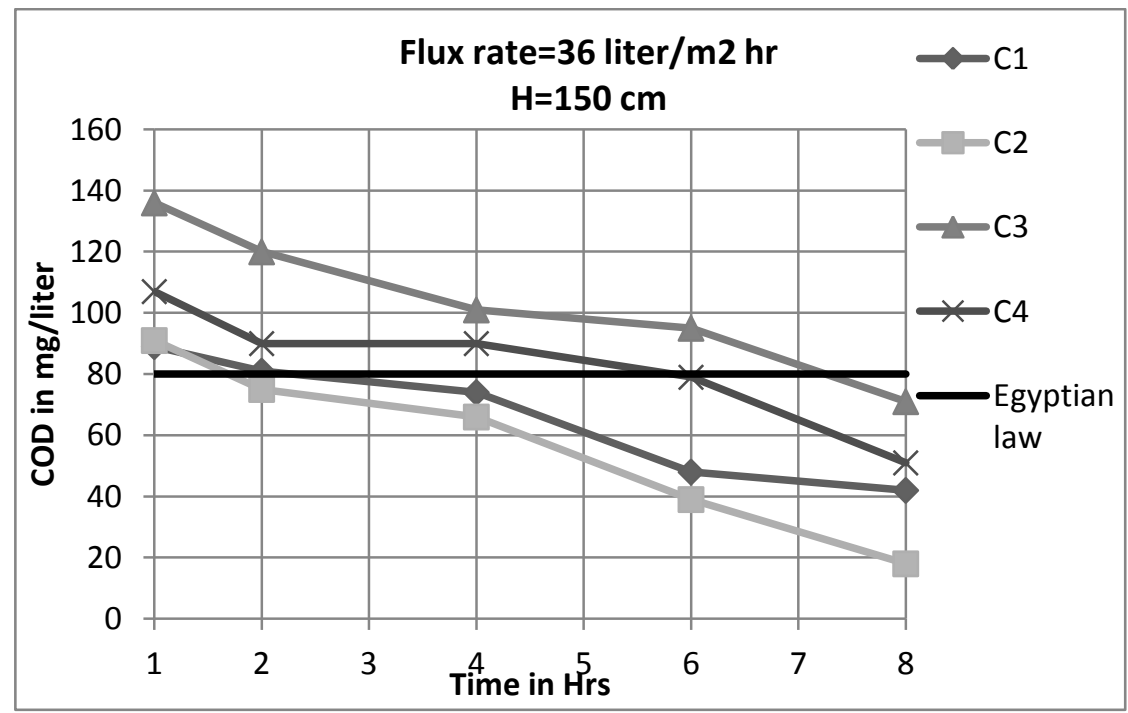

Figure (5) : COD versus Time using F1, H1

Fabrics C1, C2, C3 and C4 succeeded to reach the Egyptian law limit after 2-7 hours of operation under $\mathrm{F} 1$ and $\mathrm{H} 1$ conditions.

Fabrics C1, C2, C3 and C4 were tested for water head $(\mathrm{H} 2=175$ $\mathrm{cm}$ ) as shown in Figure (6): COD versus Time using F1, H2. 


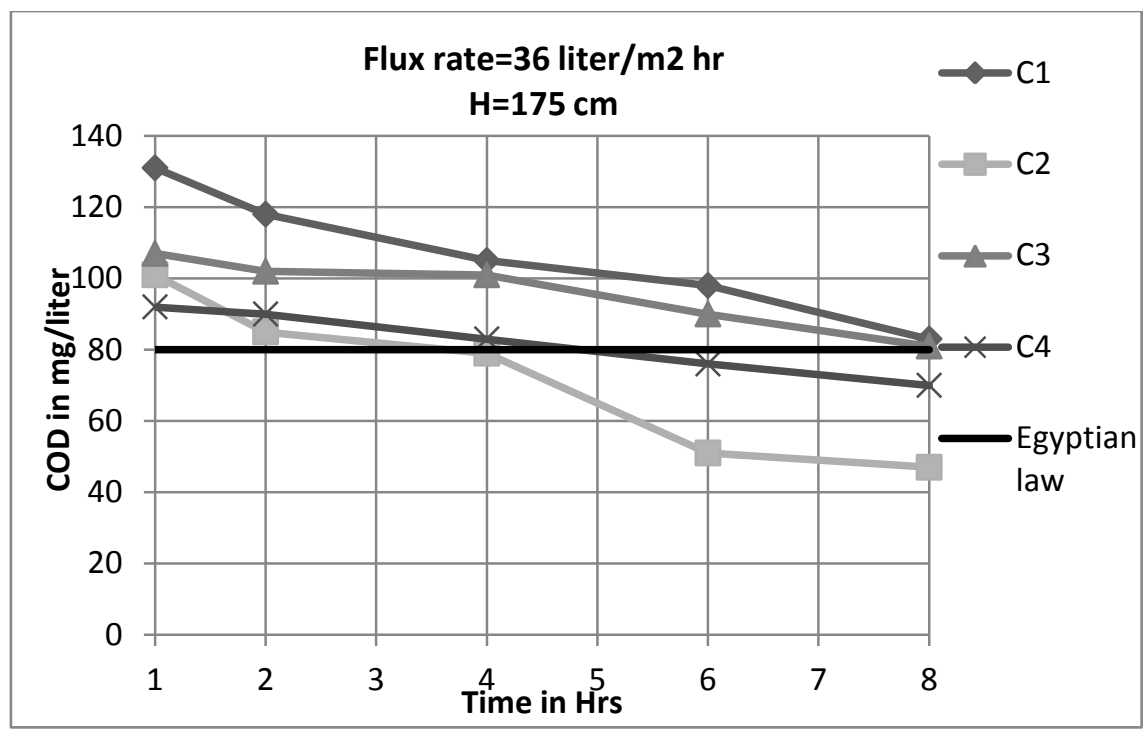

Figure (6): COD versus Time using F1, H2

Fabrics C2 and C4 succeeded to reach the Egyptian law limit after 4-5 hours of operation under $\mathrm{F} 1$ and $\mathrm{H} 2$ conditions.

Fabrics C1, C2, C3 and C4 were tested for water head $(\mathrm{H} 3=200$ $\mathrm{cm}$ ) as shown in Figure (7): COD versus Time using F1, H3. 


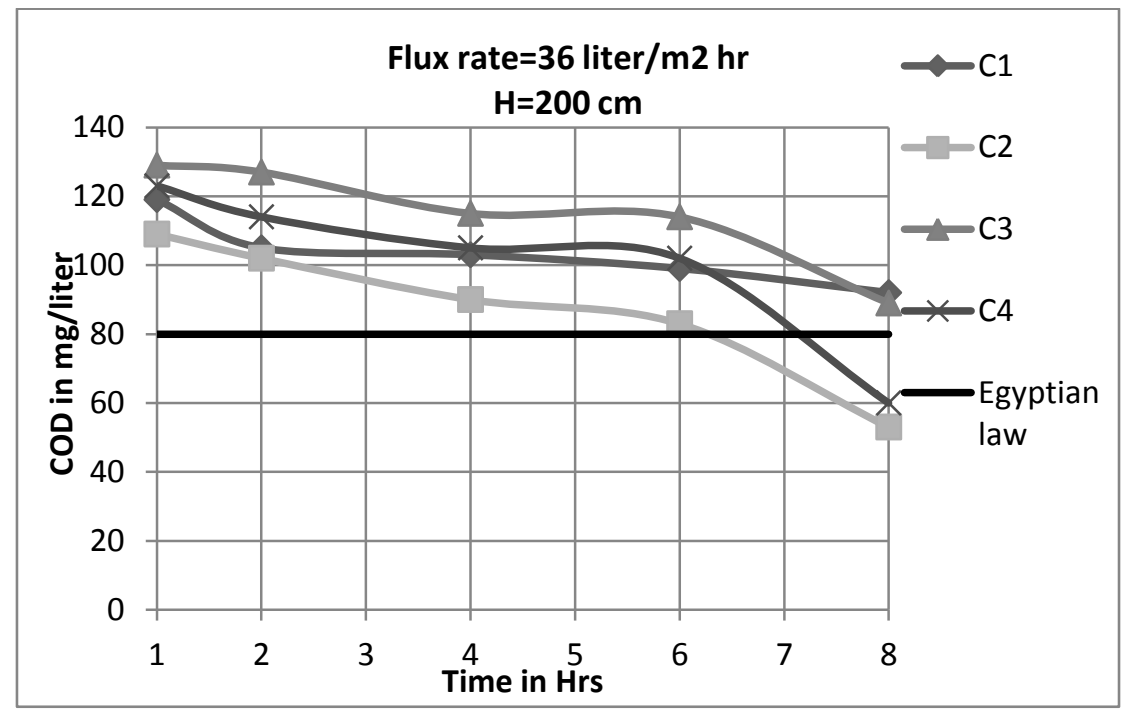

Figure (7): COD versus Time using F1, H3

Fabrics C2 and C4 succeeded to reach the Egyptian law limit after 6-7 hours of operation under F1 and $\mathrm{H} 3$ conditions.

The flux rate $\underline{F 2: 88 \mathrm{lit} / \mathrm{hr} \mathrm{m}^{2}}$ was tested for the 4 fabrics. When testing each fabric with the determined flux rate (F2), 3 water heads $(\mathrm{H} 1, \mathrm{H} 2$ and $\mathrm{H} 3)$ were tested each in a separate experiment, in order to assess the best water head and best fabric which gives the best removal efficiency for TSS and COD then compare the results with the Egyptian law limits. 


\section{TSS removal:}

Fabrics C1, C2, C3 and C4 were tested for water head $(\mathrm{H} 1=150$ $\mathrm{cm}$ ) as shown in Figure (8) : TSS versus Time using F2, H1.

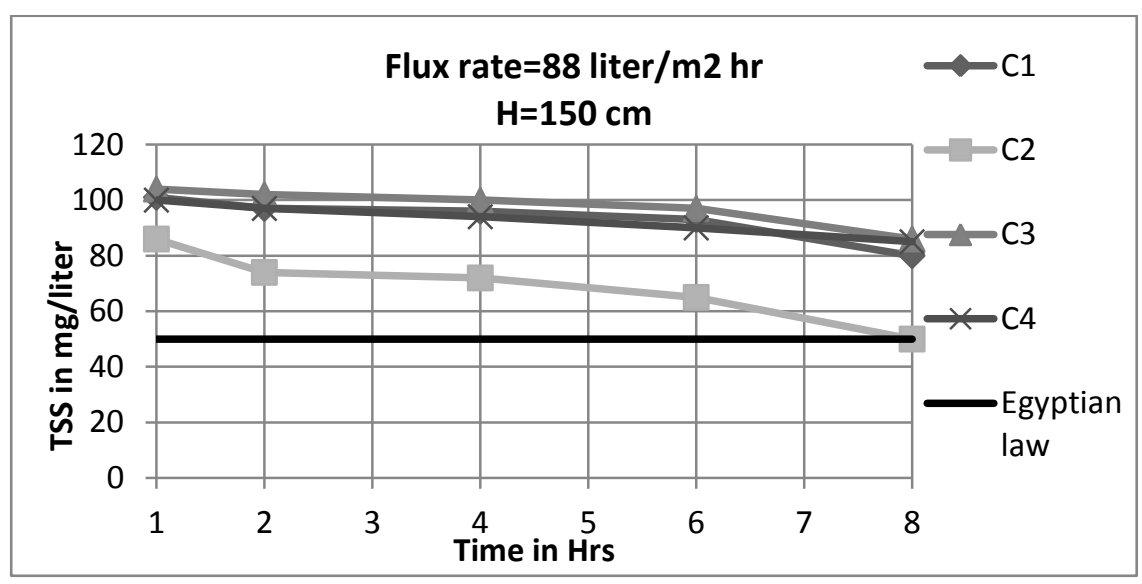

Figure (8) : TSS versus Time using F2, H1

Fabric C2 succeeded to reach the Egyptian law limit after 8 hours of operation under $\mathrm{F} 2$ and $\mathrm{H} 1$ conditions.

Fabrics C1, C2, C3 and C4 were tested for water head $(\mathrm{H} 2=175$ $\mathrm{cm}$ ) as shown in Figure (9): TSS versus Time using F2, H2. 


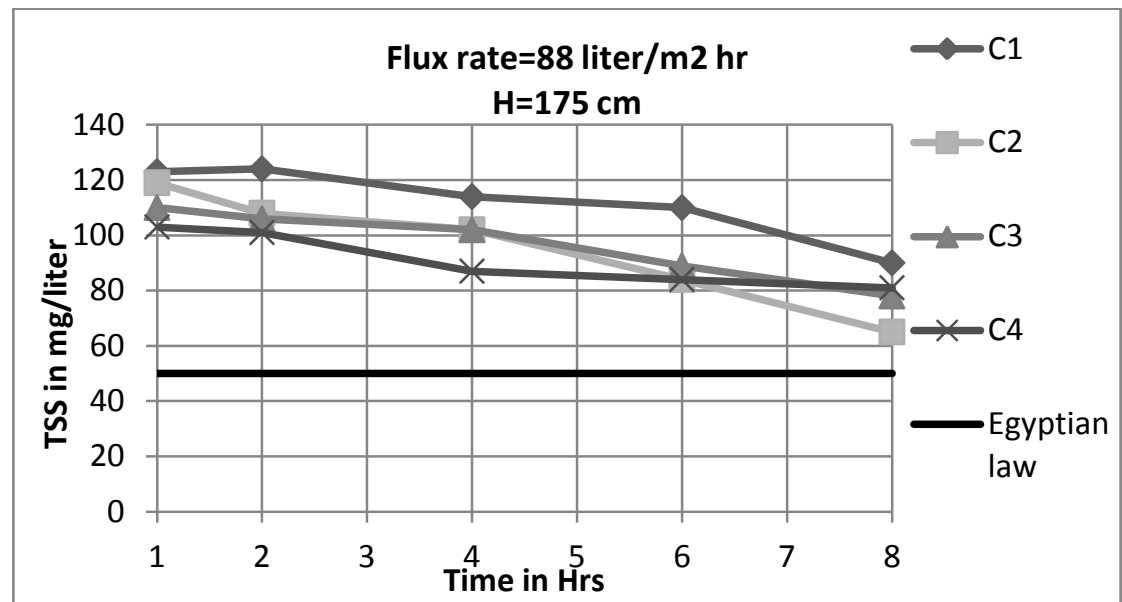

Figure (9): TSS versus Time using F2, H2

All fabrics C1, C2, C3 and C4 didn't succeed to reach the Egyptian law limit under $\mathrm{F} 2$ and $\mathrm{H} 2$ conditions.

Fabrics C1, C2, C3 and C4 were tested for water head $(\mathrm{H} 3=200$ $\mathrm{cm}$ ) as shown in Figure (10): TSS versus Time using F2, H3.

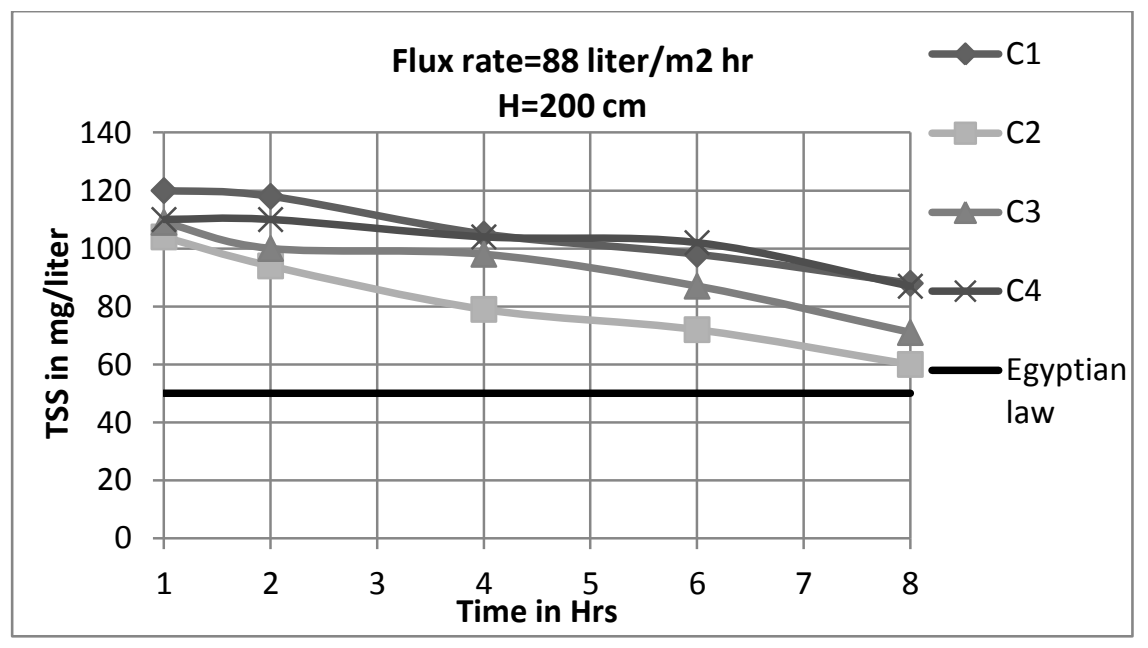

Figure (10): TSS versus Time using F2, H3 
All fabrics C1, C2, C3 and C4 didn't succeed to reach the Egyptian law limit under $\mathrm{F} 2$ and $\mathrm{H} 2$ conditions.

\section{COD removal:}

Fabrics C1, C2, C3 and C4 were tested for water head $(\mathrm{H} 1=150$ $\mathrm{cm}$ ) as shown in Figure (11): COD versus Time using F2, H1.

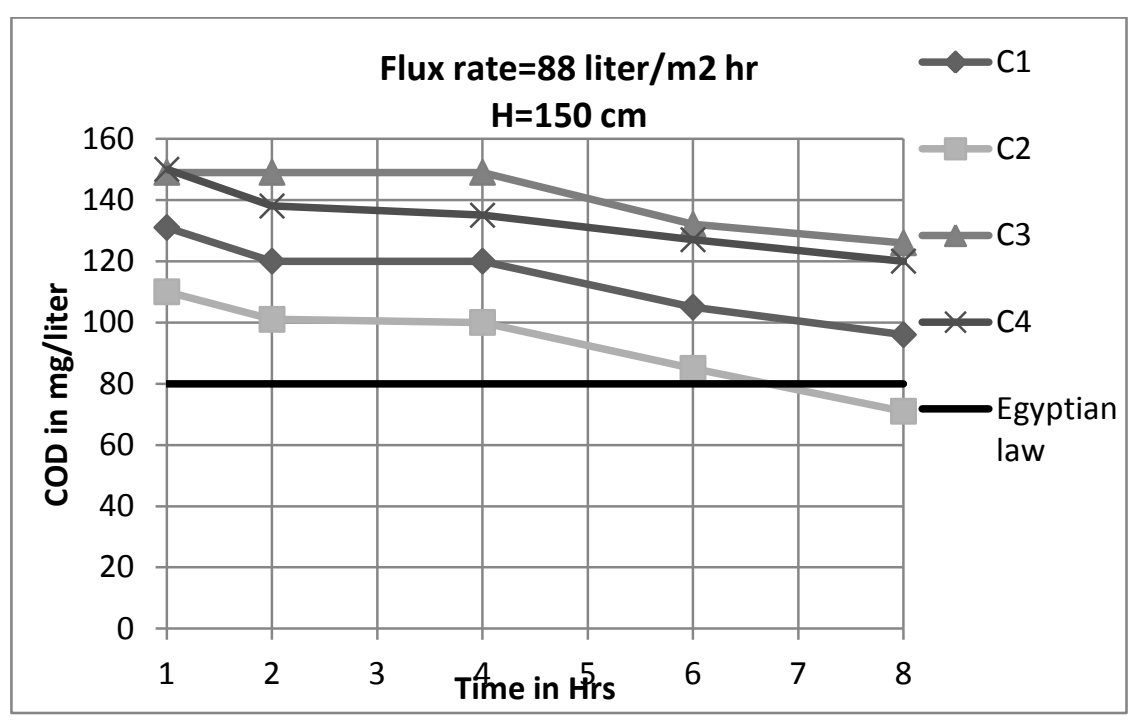

Figure (11): COD versus Time using F2, H1

Fabric C2 succeeded to reach the Egyptian law limit after 7 hours of operation under $\mathrm{F} 2$ and $\mathrm{H} 1$ conditions.

Fabrics C1, C2, C3 and C4 were tested for water head $(\mathrm{H} 2=175$ $\mathrm{cm}$ ) as shown in Figure (12): COD versus Time using F2, H2. 
J. Environ. Sci.

Institute of Environmental Studies and Research - Ain Shams University

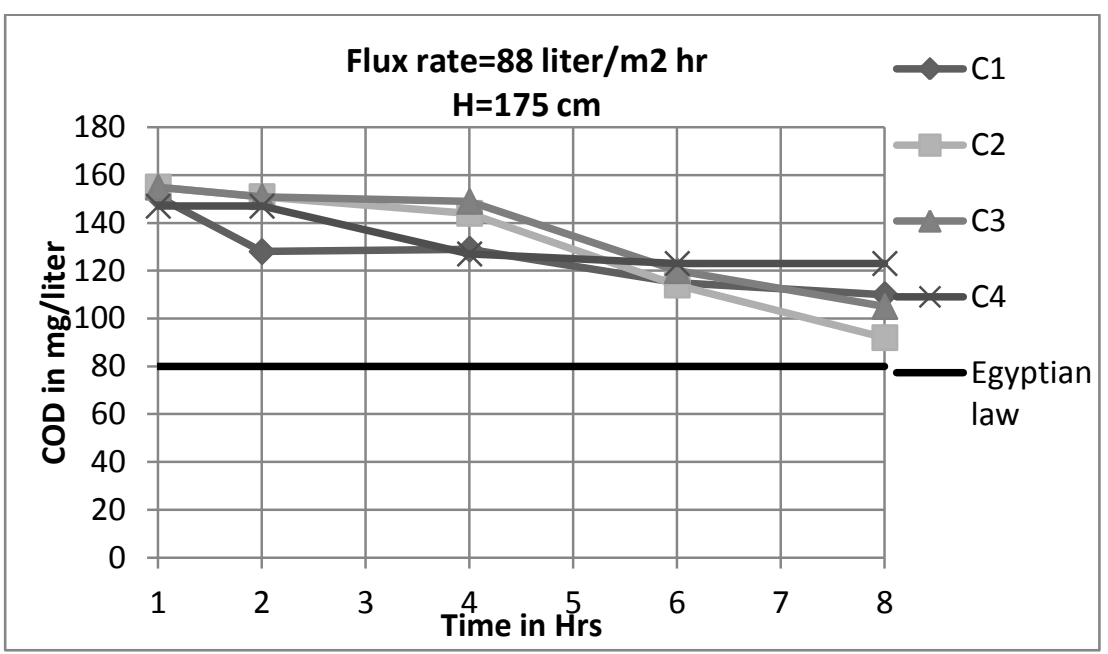

Figure (12): COD versus Time using F2, H2

All fabrics C1, C2, C3 and C4 didn't succeed to reach the Egyptian law limit under $\mathrm{F} 2$ and $\mathrm{H} 2$ conditions.

Fabrics C1, C2, C3 and C4 were tested for water head $(H 3=200$ $\mathrm{cm}$ ) as shown in Figure (13): COD versus Time using F2, H3.

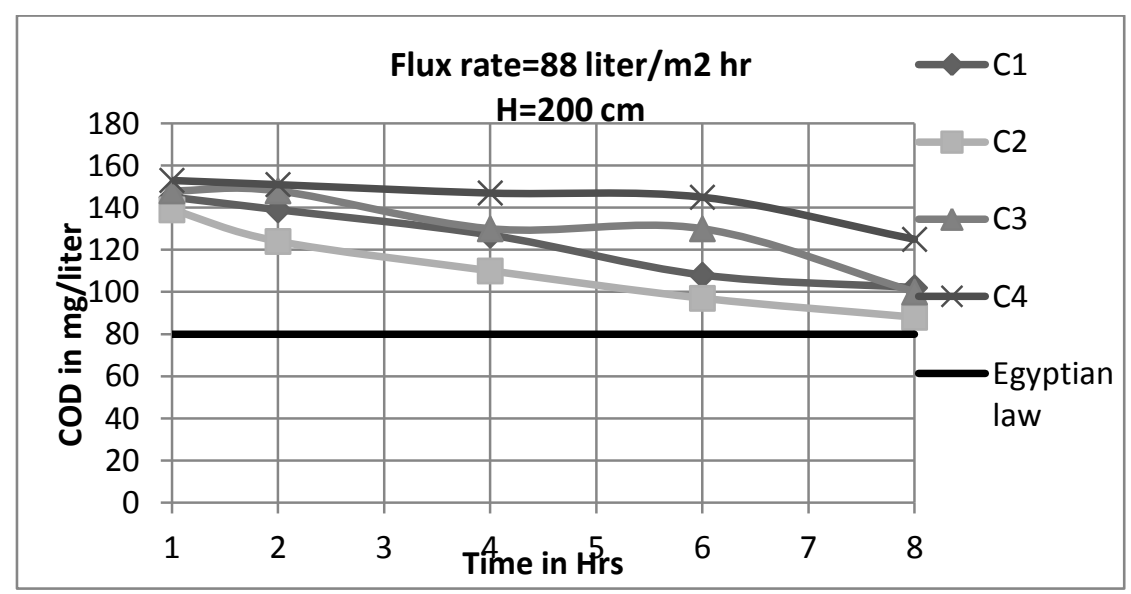

Figure (13): COD versus Time using F2, H3

Vol.33, No.1, June, 2016 
All fabrics C1, C2, C3 and C4 didn't succeed to reach the Egyptian law limit under $\mathrm{F} 2$ and $\mathrm{H} 3$ conditions.

\section{Performance Aspects:}

The removal efficiency percentage was calculated for each stage and each phase of the experiment for the two parameters, TSS and COD.

Parameter Removal Efficiency, $\%=$

$$
\left(\frac{\text { Influent Parameter } m g / L-\text { effluent parametermg / L }}{\text { Influent parameter } m g / L}\right) \times 100 \%
$$

The removal efficiency percentage was calculated for TSS and COD as shown in Table (2): Removal Performance for TSS and Table 3, Removal Performance for COD

Table (2): Removal Performance for TSS

\begin{tabular}{||c|c|c|c|c|c|c||}
\hline & \multicolumn{6}{|c|}{ High strength water } \\
\hline & \multicolumn{3}{|c|}{ F1 } & \multicolumn{3}{|c|}{ 22 } \\
\hline \hline C1 & H1 & H2 & H3 & H1 & H2 & H3 \\
\hline C2 & 87 & 79 & 70 & 50 & 43 & 45 \\
\hline C3 & 91 & 87 & 80 & 69 & 59 & 62 \\
\hline C4 & 58 & 63 & 63 & 46 & 51 & 55 \\
\hline \hline
\end{tabular}


Table (3): Removal Performance for COD

\begin{tabular}{|c|c|c|c|c|c|c||}
\hline & \multicolumn{6}{|c|}{ High strength water } \\
\hline & \multicolumn{3}{|c|}{ F1 } & \multicolumn{3}{|c|}{ F2 } \\
\hline & H1 & H2 & H3 & H1 & H2 & H3 \\
\hline C1 & 80 & 60 & 56 & 54 & 48 & 51 \\
\hline C2 & 91 & 78 & 75 & 66 & 56 & 58 \\
\hline C3 & 66 & 61 & 58 & 40 & 50 & 52 \\
\hline C4 & 76 & 67 & 71 & 43 & 41 & 40 \\
\hline
\end{tabular}

In order to identify the fabrics which are best performers, the methodology followed during this research is:

1- To exclude the fabrics having results of removal efficiencies which are less than $70 \%$.

2- To exclude the fabrics which are costly and imported

The cost and source of the selected fabric should be considered as shown in Table(4): Source and Cost of each fabric

Table(4): Source and Cost of each fabric

\begin{tabular}{|l|c|c|}
\hline \hline Fabric & Source & Cost in LE per m2 \\
\hline \hline C1 & Imported & 21 \\
\hline C2 & Imported & 60 \\
\hline C3 & Locally manufactured & 25 \\
\hline C4 & Locally manufactured & 6 \\
\hline
\end{tabular}




\section{CONCLUSIONS}

It is concluded that the high flux rate $\left(\mathrm{F} 2=88 \mathrm{Lit} / \mathrm{hr} \mathrm{m}^{2}\right)$ didn't lead to good removal efficiency $(<70 \%)$, therefore it is recommended to use the low flux rate $\left(\mathrm{F} 1=36 \mathrm{Lit} / \mathrm{hr}^{2}\right)$ which gives better removal performance results.

The fabric $\mathrm{C} 3$ didn't give the minimum removal efficiency (70\%), therefore it is recommended that $\mathrm{C} 3$ will be excluded.

The two fabrics C1, C2 gave high removal efficiency for both TSS and COD. Both are imported and of high cost, therefore, it is recommended to use those 2 fabrics if economically feasible.

The fabric $\mathrm{C} 4$ will be the fabric to be selected due to its good removal efficiency (> 70\%) and its cheap cost per square meter. It is also locally manufactured which make this fabric the best and most economic choice.

It is recommended to use the non woven polyester with specific weight is $460 \mathrm{gm} / \mathrm{m}^{2}$ and thickness of $1.08 \mathrm{~mm}$ for the partial treatment of waste water as it fulfills the Egyptian law requirement for both TSS and COD under the following conditions: Flux rate of $36 \mathrm{lit} / \mathrm{hr} \mathrm{m}^{2}$ water head of $150 \mathrm{~cm}$.

\section{REFERENCES}

El-Gendy, A.S., Sabry, T.I., \& El-Gohary, F.A. (2012): “The Use of AN Aerobic Biological Filter for Improving the Effluent Quality of A Two-Stage Anaerobic System" International Water Technology Journal (IWTJ), Volume 2, No. 4. 
El-Gendy, A.S., and Sabry, T.I. (2014): "Zero-Energy Compact Unit for Sewage Treatment in Small Communities" accepted in the IWA World Water Congress and Exhibition, to be held from 21-26 September 2014, Lisbon, Portugal.

Elmitwalli T.A., Sayed S., Groendijk L., Van Lier J., Zeeman G. and Lettinga G. (2002): Decentralised treatment of concentrated sewage at low temperature in a two-step anaerobic system; two upflow-hybrid septic tanks. Latin American Workshop and Symposium on Anaerobic Digestion (IWA) - Mexico, 22-26 October 2002.

El-Gohary F.A., (2002): "The Role of Appropriate Technologies for Wastewater Reclamation and Reuse", International Conference on Wastewater Management and its Effect on the Environment in Hot and Arid Countries. Muscat, Sultanate of Oman 12-14 Oct. 2002.

Ghobrial, F. H., Sabry, T.I.M., Wahb, I, S, and Osman M. (2008): Establishing Design Criteria for the Up Flow Septic Tank / Baffled Reactor (USBR) Use in Rural Egypt. Scientific newsletter, Faculty of engineering, El Azhar University. Vol. 30, No. 3, October 2008, pp. 1123- 1133.

Saber A. El-Shafai, El-Gohary, F.A., Johan A.J. Verreth, Johan W. Schrama and Huub J. Gijzen. (2004-A) Apparent digestibility coefficients of duckweed (Lemna minor), fresh and dry for Nile tilapia (Oreochromis niloticus), Aquaculture Research 35 (6), 574-586.

Saber A. El-Shafai, Huub J.Gijzen, Fayza A. Nasr, N. Peter van der Steen and F.A.. El-Gohary. (2004-B) Suitability of using duckweed as feed and treated sewage as water source in tilapia aquaculture, 7th International Conference of Chemical Engineering "Prospects of Oil, Gas and Petrochemical Industries in the Arab Region; Opportunities and Challenges" 27-29th December 2004, Conrad Hotel-Cairo, Egypt. 
Sabry, T.I.M. (2007-A): Application of the UASB inoculated with flocculent and granular sludge in treating sewage at different hydraulic shock loads. Bioresource Technology, ELSEVIER, 99 (2008) 4073-4077.

Sabry, T.I.M., and Sung, S. (2007-B): Demonstration of The Modified Septic Tank (USBR) for Rural Wastewater Treatment in Egypt. European Water and Wastewater Management Conference, Aqua Enviro, Newcastle, England, 24th 26th September 2007.

Sabry, T. (2007-C), Application of a new low cost wastewater treatment technology "technical and economical study". 7th Saudi Engineering Conference, King Saud University, 2-5 December, Riyadh, Saudi Arabia.

Sabry, T.I.M. (2010): Evaluation of decentralized treatment of sewage employing Upflow Septic Tank/Baffled Reactor (USBR) in developing countries. Journal of Hazardous Materials, ELSEVIER, 174: 500-505

Sabry, T.I.M., A. S. El-Gendy and F. A. El-Gohary (2011): An Integrated Anaerobic - Aerobic System for Wastewater Treatment In Rural Areas. IWA Conference 2011 Small Sustainable Solutions for Water, Venice, April 18-22.

Sabry, T.I.M. (2011): An Integrated Anaerobic - Aerobic System for Sewage Treatment. Scientific newsletter, Faculty of engineering, El Azhar University. 33(1), Jan. 2011.

Tawfik, A., G. Zeeman, Klapwijk, A., W. Sanders, F.A. El-Gohary, F. and Lettinga, G. (2003): Treatment of domestic sewage in A combined UASB/RBC system. Process optimization for irrigation purposes. Wat. Sci. Tech. 48(1), 131-138.

Tawfik, A., Klapwijk, B., Buuren, J.V., El-Gohary, F.A. and Lettinga, G., (2004): Physico-chemical factors affecting the E. coli removal in rotating biological contactor (RBC) treating UASB effluent. Water Research 38, 1081-1088. 
Young J. C. and Mccarty P.L. (1969): The anaerobic filter for waste treatment. Water Pollution Control Federation, 41(5), Part 2.

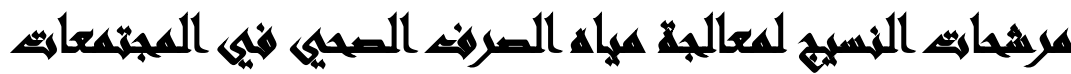 الصغيرة همص}

[9]

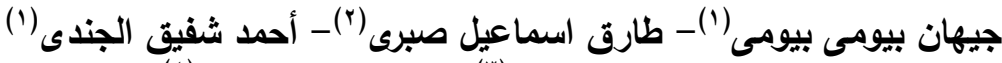

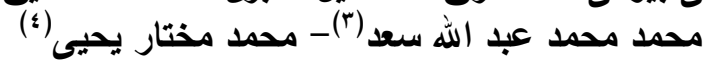

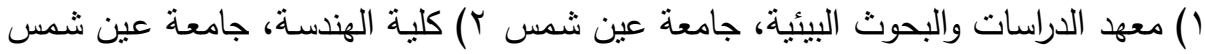

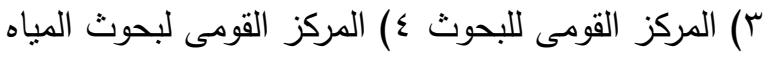

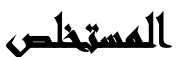

على مدار العقد الماضي، حرصت "الحكومة المصرية" على توجيه مقدار كبير من

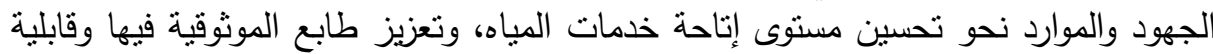

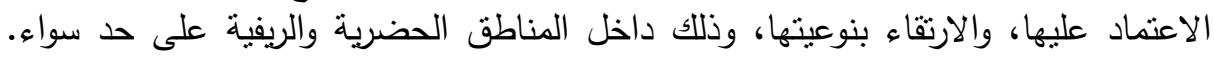

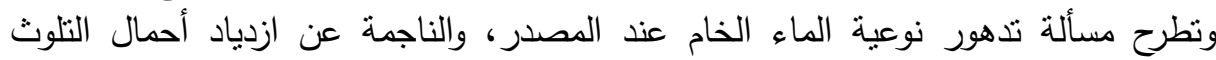

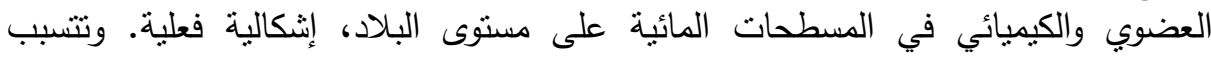

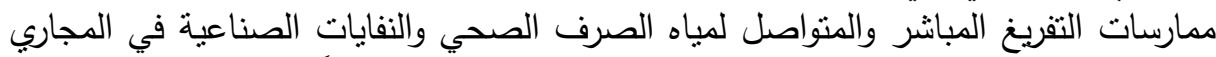

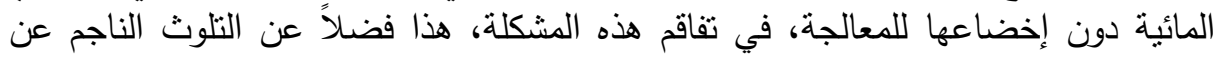
الإفراط في استخدام الأسمدة الكيمائية والمبيدات الماتية الحشرية.

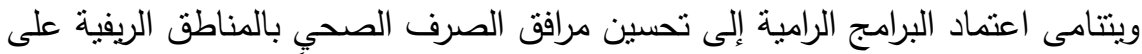

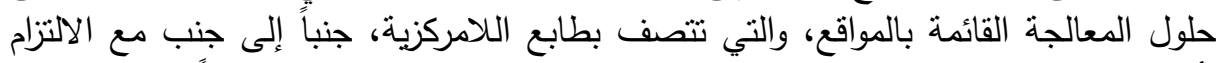

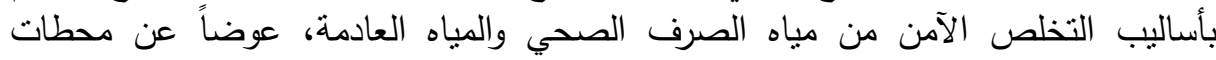

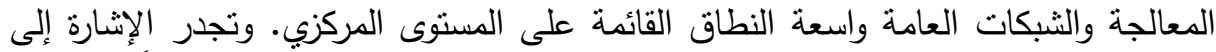

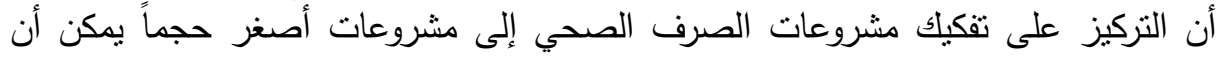

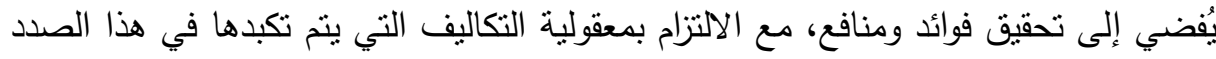

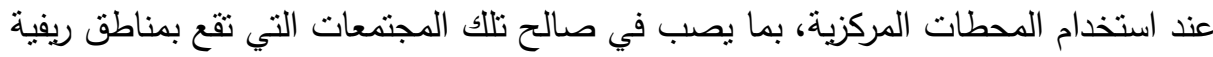
والتى يشتد فيها الاحتياج لتلك الخدمات. 


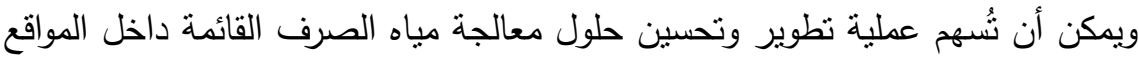

والتي تتميز بالطابع اللامركزي في القضاء على المشكلات البيئية، بالإضافة إلى الهئ الوقاية من

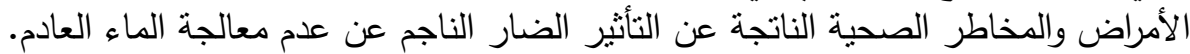

